\title{
THE EFFECTIVITY OF SCAFFOLD FROM ANADARA GRANOSA SHELL-STICHOPUS HERMANNION BLOOD VESSEL COUNTS AFTER TOOTH EXTRACTION
}

\author{
Rima Parwati Sari*, Chaterina Diyah Nanik Kusumawardani**, Dian Widya Damaiyanti* ${ }^{*}$ A. Retno Pudji \\ Rahayu ${ }^{\star * *}$, Sri Agus Sudjarwo**** \\ * Department of Oral Biology, Faculty of Dentistry, Universitas Hang Tuah \\ ** Department of Prosthodontic, Faculty of Dentistry, Universitas Hang Tuah \\ *** Department of Oral Pathology and Maxilofacial, Faculty of Dental Medicine, Airlangga University \\ ${ }^{* * * *}$ Department of Pharmacology, Faculty of Veterinary Medicine, Airlangga University \\ Correspondence: rima.parwatisari@hangtuah.ac.id
}

\section{Keywords:}

Anadara granosa shell; Stichopus hermanni; tooth extraction, blood vessel

\begin{abstract}
Background: Alveolar bone resorption can occur after tooth extraction. One source of bone scaffold material is hydroxyapatite and tricalcium phosphate (HA-TCP). The shell of Anadara granosa can be synthesized to be HA-TCP. Hyaluronic acid, which is widely contained in Stichopus hermanni, can stimulate endothelial progenitor cells for the healing process.

Purpose: This research aims to prove the Effectivity of scaffold from Anadara granosa shell-Stichopus hermanni on blood vessel counts after tooth extraction.

Methods: The sample in this study was male Wistar rats divided into four study groups randomly. Each group consists of 6 rats. Extraction was carried out on the mandibular first incisor, then was given gelatin as a placebo in the control group, treatment groups given scaffold from Anadara granosa shells (AG), and scaffold combination from Anadara granosa shells-Stichopus hermanni with concentrations of 0.4\%-0.8\%. (AGSH1-AGSH2). Development of HA-TCP synthesized from Anadara granosa combined with Stichopus hermanni extract for biomedical scaffolds using the freeze-dried method. Observations were made three days after tooth extraction. Data analysis has used one-way ANOVA followed by Tukey HSD $(p<0.05)$.

Results: The results of the ANOVA test followed by the HSD-Tukey test showed a significant difference between $C$ (7.33 \pm 1.51$)$ and AGSH1

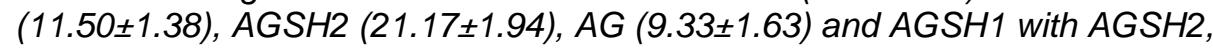
but between $A G$ and, AGSH1 no significant differences.

Conclusions: Combination scaffold from Anadara granosa shell and Stichopus hermanni $0.8 \%$ effectively increased blood vessel counts after tooth extraction.
\end{abstract}

\section{INTRODUCTION}

Indonesian Basic Health Research 2013 showed index M-T (missing teeth) scores 2.9 which expresses the number of permanent teeth extraction is 290 for 100 patients of tooth decay. This number considered high as if we compare it to F-T (filling teeth) index which scores $0.08 .{ }^{1}$ Posttooth extraction, in general, are likely to cause the decreasing of alveolar ridge height and morphology changes, which in turn, can lead into bone resorption and moreover will be disruption in the stomatognathic system. ${ }^{2}$

Post-tooth extraction, the socket healing process involves several phases, namely the inflammatory phase, the proliferative phase, and the remodeling phase. The proliferation phase will begin on the third day after tissue injury. This phase was characterized by fibroblasts migration, 
extracellular matrix deposition, collagen synthesis, angiogenesis, and granulation tissue formation. ${ }^{3}$ Angiogenesis plays a crucial role in the wound healing process by supplying oxygen and nutrition to support cell metabolism. ${ }^{4,5}$ Angiogenesis is directly involved in maintaining functions of impacted tissue and organ. ${ }^{6}$ Angiogenesis is a biological process in which new blood vessels form from the pre-existing vessels. It occurs throughout life in both health and disease. Angiogenesis happened in several stages. In the initiation stage, the protease enzyme was released from activated endothelial cells. The formation of vascular blood vessels, such as extracellular matrix degradation (Extracellular Matrix, ECM), migration and proliferation of endothelial cells, and the construction of new ECM, continued with maturation or stabilization of blood vessels controlled and modulated to comply with tissue need. ${ }^{6}$

The latest improvement in medical science nowadays has brought a big impact in increasing patient's life rate. A high demand in society of esthetic and physiological, the people's awareness about health and comfort and the development of latest technology, has presenting an alternative treatment to prevent the bone damage or bone loss. ${ }^{7}$ Bone graft was one of the alternative treatment to it.

Analog to calcium phosphate, Hydroxyapatite (HA), is a dominant crystal form in bone tissue and role in mechanical strength to the tissue, it also showed bioactive properties because of its osteoconductive characteristic, hence slowler or not absorbable.8,9 Tricalcium phosphate (TCP) as the rich source of calcium and phosphor, can be easily asimilated and resorbable. Beta-calcium phosphate was biocompatible and create a resorbable interconnection in defect area to increase bone healing process. ${ }^{8}$ Addition of $\beta$ tricalcium phosphate $\left(\beta-T C P=\mathrm{CA}_{3} \mathrm{PO}_{42}\right)$ will help the elaboration of hydroxyapatite and reduce the existence of negative effect. ${ }^{10}$

Blood cockle shells (Anadara granosa) is one of an useless wasted. Preliminary study has represented that blood cockle shells consists of $100 \% \mathrm{CaCO}_{3}$ mineral and can be synthesized by hydrothermal method with the $200^{\circ} \mathrm{C}$ temperature for 12 hours to form $72 \% \mathrm{HA}$ and $21 \%$ TCP.

Scaffold is one of the bone graft used to support cell for proliferating and maintaining its function. The ideal scaffold can be achieved by adding polimer ingredients to restore bone function and growth tissue. ${ }^{11}$ There are some of graft materials with polimer ingredients such as, gelatin, chitosan and hialuronat acid. These materials was chosen because it has a site that can be added by chemical, protein, peptides and another cells to form a scaffold. ${ }^{12}$

Previously research that had been conducted with characterization of GAGs content in sea cucumber using spectrofotometer, showing that hyaluronat acid $(\mathrm{AH})$ is the highest content $(75,7 \%)$, followed by heparan sulfate (2\%), chondroitin sulfate $(1.72 \%)$ and dermatan sulfate $(1.11 \%)$. AH has a significant role in affecting the motion of cell migration in wound healing, inflammation, angiogenesis, reepitalization and cell proliferation processes..$^{13} \mathrm{~A}$ research conducted by Sari et.al ${ }^{14}$ showed that gel etanol extract of Stichopus hermanni has ability to modulate fibroblast growth factor-2 (FGF-2) in day 1 and day 2 after traumatic ulcer induced. Another research that is done by Sari et.al. ${ }^{15}$ showed that graft augmentation from Anadara granosa shell powder and Stichopus hermanni gel potentially increasing angiogenic factor by raising basic fibroblast growth factor (bFGF) expression and blood vessels count on rat wistar with defect at tibia bone. $\mathrm{AH} 0.8 \%$ gel has an impact to the rate of wound healing process post 
mandibular symphysis fracture. ${ }^{16}$ Additionally, there was another studies using $\mathrm{AH}$ of $0.8 \%$ concentration concluded that $\mathrm{AH}$ accelerated bone regeneration through a complex series of processes including angiogenesis. ${ }^{17}$ Based on the above description, therefore should be done research about the effectivity of scaffold from Anadara granosa shell combined with Stichopus hermanni on blood vessels count after tooth extraction.

\section{METHODS}

This research is true experimental using a completely randomized design. The criteria for experimental unit is male rats (Rattus novergicus) weighing 200-250 grams and aged 2-3 months. The rats were then divided into four groups $(n=6)$, namely : the group that was not treated (control); the group with the administration of scaffold from $A G$ shells only (AG); the group with the administration of scaffold from a combination of $A G$ shells and $0.4 \%$ Stichopus hermanni (AGSH1) ; the group with the administration of scaffold from a combination of $A G$ shells and $0.8 \%$ Stichopus hermanni (AGSH2).

Research preparation began with synthesizing HA-TCP from the Anadara granosa shell using the hydrothermal method. Mixing $0.6 \mathrm{M}$ $\mathrm{NH}_{4} \mathrm{H}_{2} \mathrm{PO}_{4}$ solution and $1 \mathrm{M}$ Anadara granosa solution with a magnetic stirrer for 30 minutes, then transferred to the reactor. The reactor was put into the furnace oven and heated at $200^{\circ} \mathrm{C}$ for 12 hours and cooled. Furthermore, the powder was washed with distilled water repeatedly until it showed a $\mathrm{pH}$ of 7 . The last washing was using methanol to minimize the agglomeration of powder particles during drying. The samples were dried in an electric oven at $50^{\circ} \mathrm{C}$ for 4 hours. The next step is sintering at $900{ }^{\circ} \mathrm{C}$ for 3 hours to remove impurities and increase the crystallinity of the sample. ${ }^{18}$
The beginning of preparing the Stichopus material was to wash it with sterile distilled water and blended it with sterile distilled water at a ratio of $1: 2(w / v)$ until smooth. Drying was done by the freeze-drying method. The freeze-dried powder was finely milled and sieved with a mesh size of 50 (297 microns). Next, milling to a smaller size using Elliptical 3D Motion (HEM-E3D) high energy milling by $\mathrm{Nanotech} \AA$ Indonesia. The freeze-dried powder was finely milled and sieved with a mesh size of 50 (297 microns). Next, milling to a smaller size using Elliptical 3D Motion (HEM-E3D) high energy milling by $N$ anotech $\AA$ Indonesia. ${ }^{19}$

The next step is making scaffold with freeze-dry method. The first thing to do was make an HA-TCP solution obtained from $5 \mathrm{~g}$ of blood clamshell (Anadara granosa) dissolved in $50 \mathrm{ml}$ distilled water. They were then making the polymer by dissolving gelatin $10 \mathrm{~g}$ into $50 \mathrm{ml}$ of distilled water. The two solutions were mixed with a ratio of $1: 1$, as for the making scaffolds from a combination of AG shell and Stichopus hermanni, added Stichopus hermanni, which has dissolved $\mathrm{NaOH}$, as much as $0.4 \mathrm{~g}$ and $0.8 \mathrm{~g}$ into $100 \mathrm{ml}$ of the scaffold solution. Stirring is carried out with a magnetic stirrer for 4 hours, put into 96 well plates, put into a freezer of $-80{ }^{\circ} \mathrm{C}$ for at least 24 hours, and dried using the freeze-drying method. The final stage of preparing this scaffold is radiation with gamma rays of $25 \mathrm{kGy}$ by BATAN. ${ }^{20}$

Wistar rats were acclimatized for one week and rats were fasted overnight before conducting the study. Randomization of samples into groups was carried out before weighing and marking. Furthermore, the rat was anesthetized using 10\% ketamine at a dose of $0.1 \mathrm{cc} / \mathrm{kg}$ body weight and xylazine $0.01 \mathrm{cc}$ per $100 \mathrm{~g}$ body weight in the right upper thigh (intramuscular). ${ }^{19}$ Make sure the rat has been affected by anesthesia marked by a corneal reflex missing before the reflexes of the foot 
retraction are lost. After that, asepsis was carried out in the extraction area with aquadest irrigation and antiseptic fluid. Then the lower left incisor was extracted in Wistar rats using a needle holder and immediately applied scaffold.

Suturing using a silk braid (USP. 3/0) from DR. SELLA ${ }^{\circledR}$ to close the socket. Analgesic novalgin $^{\circledR} 0.09$ cc per 200 gr body weight and antibiotic interflox $0.1 \mathrm{cc}$ per $100 \mathrm{gr}$ body weight were administered to control swelling and pain. 3 days after application in the socket, the animal was sacrificed and os mandibular specimen was taken and put into a $10 \%$ formalin buffer solution. The decalcification process was then carried out using ethylenediaminetetraacetic acid (EDTA) for one month. Os mandibular specimen was sectioned transversely with $\mathrm{HE}$ staining. After that, the number of blood vessels was observed in the apical 2/3 of the socket with a light microscope (Olympus ${ }^{\circledR}$ CX21, Japan) at 100X magnification. Furthermore, the data were tabulated and statistically analyzed by One-way ANOVA and HSD-Tukey test.
The number of blood vessels were obtained from observations at $2 / 3$ apical socket histopathology sections with HE staining. The results of observation through a light microscope with a magnification of $100 \mathrm{X}$ can be seen in Figure 1. In the ANOVA test found a significant difference in the results of the mean number of blood vessels $(p=0,000)$.

The characteristics of blood vessels are lumen formation surrounded by a layer of endothelial cells seen in the area of the femur that has a defect (Figure 1).

Vascular observation showed in group $\mathrm{K}=7.33$ $\pm 1.51 ; \mathrm{AG}=9.33 \pm 1.63 ; \mathrm{AGSH} 1=11.50 \pm 1.38$; AGSH2=21.17 \pm 1.94 (Figure 2).

Multiple comparison results HSD showed the significant differences of $\mathrm{C}$ control group to AGSH1-2 group, AG group and AGSH1 group to AGSH2 group. Insignificant differences showed between $C$ group to $A G$ group and $A G$ group to AGSH1 group (Table 1). Vascular observation showed in group $\mathrm{K}=7.33 \pm 1.51 ; \mathrm{AG}=9.33 \pm 1.63$; AGSH1=11.50 $\pm 1.38 ; A G S H 2=21.17 \pm 1.94$ (Figure 2).

\section{RESULTS}
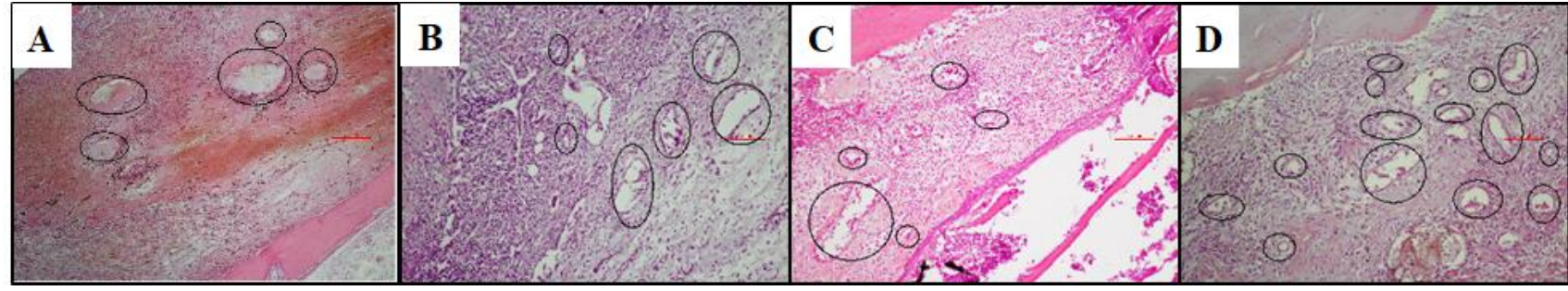

Figure 1. Histologic section of blood vessels at the apical $2 / 3$ socket

A. K group (Control group given scaffold from gelatin); B. AG group (group given scaffold from Anadara granosa shell); C. AGSH1 group (group given scaffold from Anadara granosa shell-Stichopus hermanni 0,4\% combination); D. AGSH2 Group (The group given scaffold $0.8 \%$ Anadara granosa-Stichopus hermanni $0.8 \%$ combination scaffold)

Multiple comparison results HSD showed the significant differences of $\mathrm{C}$ control group to AGSH1-2 group, AG group and AGSH1 group to
AGSH2 group. Insignificant differences showed between $C$ group to $A G$ group and $A G$ group to AGSH1 group (Table 1). 


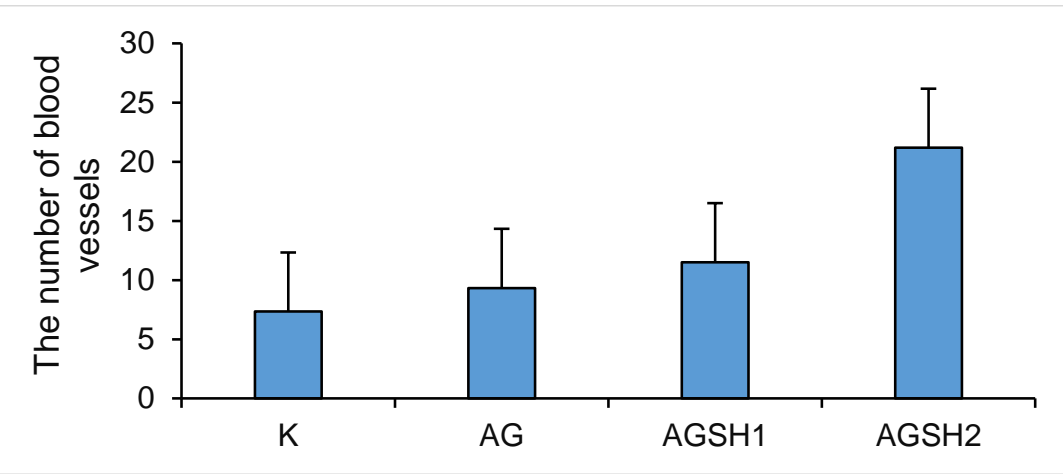

Figure 2. The chart of application effect of scaffold on blood vessels.

The result showed group receiving combination of Anadara granosa shells and Stichopus hermanni $0.8 \%$ (AGSH2) the highest number of blood vessels, while the lowest number of blood vessels in control group $(n=6)$.

Table 1. Results of the Post-Hoc HSD tukey test for the number of blood vessels

\begin{tabular}{cccc}
\hline \multicolumn{2}{c}{ Average } & Mean Difference (I-J) & P Valvue \\
\hline Group (I) & Group (J) & & .211 \\
\hline K & AG & -2.000 & .001 \\
\hline & AGSH1 & $-4.167^{*}$ & .000 \\
\hline AG & AGSH2 & $-13.833^{*}$ & .152 \\
\hline & AGSH1 & -2.167 & .000 \\
\hline AGSH1 & AGSH2 & $-11.833^{*}$ & .000 \\
\hline
\end{tabular}

Note: This table shows the comparison of the mean number of blood vessels between groups. The average number of blood vessels in group AGSH greater than groups K and AG. The greatest of blood vessels is AGSH2.

\section{DISCUSSION}

The formation of new blood vasculature from preexisting vessels, a process called angiogenesis, is critical to the beginning of bone repair, because of oxygen supply and nutrition that play an important role to support cell metabolism in cell regeneration process. ${ }^{4}$ Angiogenesis in socket healing begin at the second day after tissue injury, whereas, in regular healing process, angiogenesis initiation begin due to local releasing of pro and antiangiogenic growth factors by endothelial cells, as a respon to injury which induced inflammation and Hypoxia-Inducible Factor-1a (HIF-1a) accumulation. ${ }^{21}$ This circumstances will cause endothelial cells to provoke $b F G F$, to form a microvascular growth. The next phase is fibroblast growth factor (FGF) and vascular endothelial growth factor (VEGF) attached to the receptors in surface cell, followed by tyrosine kinase activities which mediated the integration of signal transduction pathway to regulate proliferation, migration, and differentiation endothelial cells. ${ }^{22}$ These can be seen at control group, where blood vessels still can be found (Figure $1 \mathrm{~A}$ ).

HA-TCP application from the synthesized of Anadara granosa shell in this research, functionate as a scaffold. Scaffold from HA-TCP expected to have mineral cavities that is connected one to another, thus allows the adhesion of mesenchyme cell to differentiate forming a new blood vessels. ${ }^{23}$ In this study, we can conclude that the increased blood vessels was found in AG group, although in the multiple comparison HSD test, there was no significant differences with $\mathrm{C}$ group. This means that scaffold from HA-TCP alone was not enough to improve the blood vessels count significantly to accelerate angiogenesis process. 
Hyaluronic acid is one of the main ingredients found inside Stichopus hermanii $(75,7 \%)$ and play an important role in adhesion, proliferation and cell mobility. Signaling of hyaluronic acid is essential for angiogenesis regulation, especially in affecting endothelial cell characteristic. CD44 (glicoprotein transmembranous tipe 1) and Receptor for Hyaluronan-Mediated Motility (RHAMM) are two main receptors of hyaluronic acid, which found in the surface of endothelial cells. CD44 and RHAMM stimulated by hyaluronaic acid oligonomer, then activated mitogen-activated protein kinase (MAPK), which lead to the constant activation of extracellular signal-regulated protein kinase 1/2 (ERK 1/2) and activation of transcription activator protein-1 (AP-1) and accelerated cell motility. ${ }^{24}$ Active transcription of target gen AP-1 induced transduction pathway which generated induction of cell migration by releasing some growth factors, such as FGF, VEGF and TGF $\beta$ as an angiogenic factor. ${ }^{25}$

This research also showing the result of blood vessels count in both AGSH1 and AGSH2 group increased compared to the $C$ group and $A G$ group. In the third day, AGSH2 group showed the highest count of blood vessels. HRD comparison multiple test showing that AGSH2 with $0.8 \%$ concentration of Stichopus Hermanni is more effective than $0.4 \%$ concentration, and was the most effective group among others.

\section{CONCLUSION}

We conclude that combination scaffold from of Anadara granosa shell and sea cucumber (Stichopus Hermanni) are effective to the increase number of blood vessels in the socket healing after tooth extraction.

\section{ACKNOWLEDGEMENT}

This research was supported by the Scientific Project Fund from Universitas Hang Tuah.

\section{REFERENCES}

1. Badan Penelitian Dan Pengembangan Kesehatan. Riset Kesehatan Dasar 2013. Badan Penelitian Dan Pengembangan Kesehatan, Kementerian Kesehatan RI. 2013. P. 110-119

2. Van der Weijden F, Dell'Acqua F, Slot DE. Alveolar bone dimensional changes of postextraction sockets in humans: a systematic review. J Clin Periodontol 2009; 36: 10481058.

3. Velnar T, Bailey T, Smrkolj V. The Wound Healing Process: An Overview of The Celluler and Molecular Mechanisms. The Journal of International Medical Research, 2009, 37(5): 1528-1542.

4. Mitchell RN, Kumar V, Abbas AK, Fausto N, Aster J. Pocket companion to Robbins and Cotran: Pathologic Basis of Disease. $8^{\text {th }}$ edition. Buku Saku Dasar Patologis Penyakit. Saunders. 2011. p. 57-75

5. Tonnesen MG, Feng $X$, Clark RAF. Angiogenesis in wound healing. Department of Dermatology, Health Sciences center T16060, SUNY at Stony Brook, Stony Brook, NY 117948165, New York. 2000. p. 40-46

6. Frisca, Sardjono CT dan Sandra F. Angiogenesis: Patofisiologi dan Aplikasi Klinis. JKM, 2009, 8(2): 174-187.

7. Da Costa GC, Aras M, Chitre V. Failures in Dental Implants. J Adv Med Dent Scie 2014;2(1):68-81.

8. Sulaiman $\mathrm{SB}$, Keong $\mathrm{TK}$, Cheng $\mathrm{CH}$, Saim $\mathrm{AB}, \mathrm{Hj} \quad$ Idrus RB. Tricalcium phosphate/hydroxyapatite (TCP-HA) bone scaffold as potential candidate for the formation of tissue engineered bone. Indian $\mathrm{J}$ Med Res. 2013 Jun; 137(6): 1093-1101

9. Rujitanapanicha, Kumpapanb P, Wanjanoi P. Synthesis Of Hydroxyapatite From Oyster Shell Via Precipitation. Sawittree Energy Procedia 2014; 56 : p. $112-117$

10. Mao K, Zhou F, Cui F, Li J, Hou X, Li P, Du $M$, Liang $M$, Wang $Y$. Preparation And Properties Of A-Calcium Sulphate Hemihydrate And B-Tricalcium Phosphate Bone Substitute. Biomed Mater Eng 2013. Vol. 23 (3):p.197-210 
11. Mao T, Kamakshi V. Bone Grafts And Bone Substitutes. International Journal of Pharmacy and Pharmaceutical Sciences 2014; Vol 6 suppl $2: 88-91$

12. Kheirallah M, Almeshaly $H$. Bone Graft Substitutes for Bone Defect Regeneration. A. Collective Review. International Journal of Dentistry and Oral Science, 2016, 3: 247-257

13. Gomes JAP, Amankwah R, Powel-Richards A, Dua HS. Sodium Hyaluronate (Hyaluronic Acid) Promotes Migration of Human Corneal Epithelial Cells in Vitro. British Journal of Opthalmology. 2004; 88: 821-825

14. Sari RP, Wahjuningsih E, Karsini I. Modulation of FGF2 after topical application of Stichopus hermaniigelon traumatic ulcer in Wistar rats. Dent. J. (Maj. Ked. Gigi), September 2014; 47 (3) : 126-129

15. Sari RP, Sudjarwo SA, Rahayu ARP, Prananingrum W, Revianti S, Kurniawan $\mathrm{H}$, Bachmid AF. The effects of Anadara granosa shell -Stichopus hermanni on bFGF expressions and blood vessel counts in the bone defect healing process of Wistar rats. Dent. J. (Maj. Ked. Gigi) 2017 Desember; 50(4): 194-198

16. Widiyanta E, Rahmat M, Rahajoe PS. Pengaruh pemberian Asam hialuronat jeli 0,8\% terhadap kecepatan penyembuhan luka pasca fraktur simpisis mandibular. Jurnal kedokteran gigi, 2011; II (3): 164-173

17. Dahiya P, Kamal R. Hyaluronic Acid: A Boon In Periodontal Therapy. N Am J Med Sci 2013; Vol. 5(5):309-15
18. Earl JS, Wood DJ, Milne SJ. Hydrothermal synthesis of hydroxyapatite. Journal of Physics: Conference Series 2006; 26 : 268-271

19. Balaz P. Mechanochemistry in Nanoscience and Minerals Engineering. Springer-Verlag Berlin Heidelberg 2008 : 103-132

20. Tanideh N, Nazhvani SD, Jaberi FM, Mehrabani D, Rezazadeh S, Pakbaz S, Tamadon A, Nikahval B. The Healing Effect of Bioglue in Articular Cartilage Defect of Femoral Candyle in Experimental Rabbit Model. Iranian Red Crescent Medical Journal , 2011 ; 13(9): pp.629-33

21. Kyzas PA, Stefanou D, Batistatou A, Agnantis NJ. Hypoxia-induced tumor angiogenic pathway in head and neck cancer: an in vivo study. Cancer Lett 2005; 225:297-304.

22. Yin S, Ellis DE. First-Principles Investigations Of Ti-Substituted Hydroxyapatite Electronic Structure. Physical Chemistry Chemical Physics Issue. 2010.

23. Xiao X, Wang W, Liu D, Zhang H, Gao P, Geng L, Yuan Y, Lu J, Wang Z. The promotion of angiogenesis induced by three-dimensional porous beta-tricalcium phosphate scaffold with different interconnection sizes via activation of PI3K/Akt pathways. Scientific Reports, 2015; 5 (9409):1-11

24. Litwiniuk M, Krejner A; Grzela T. Hyaluronic Acid In Inflammation And Tissue Regeneration. Wounds $2016 ; 28(3): 78-88$

25. Schwertfeger KL, Cowman MK, Telmer PG, Turley EA, McCarthy JB. Hyaluronan, Inflammation, And Breast Cancer Progression. Front Immunol. 2015; 6 (236) : 1-12 